\title{
An integrated programme for local Floras, conservation research and environmental awareness generation in South India
}

\author{
K. M. Matthew
}

\begin{abstract}
K. M. Matthew (The Rapinat Herbarium, St Joseph's College, Tiruchirapalli 620002 \& The Anglade Institute of Natural History, Shembaganur, Kodaikanal 624 104, India) 2003. An integrated programme for local Floras, conservation research and environmental awareness generation in South India. Telopea 10(1): 73-80. Three components of the work reported here (local Floras, conservation of endangered species, and a programme for environmental awareness generation involving the neighbourhood community), are integral parts of a holistic eco-restoration programme in South India. It is hoped that this successful model addressing an issue of such vital urgency, especially in the tropics, could be replicated elsewhere at least in essentials. The first component is publishing an affordable, illustrated, modern Flora of the region based on adequate fieldwork. Publication would be initially in English and later in the vernacular. The second component would be a concurrent programme of conservation research on locally endangered species, and the third would be to generate environmental awareness at the local community level.
\end{abstract}

\section{Local Floras}

\section{The technical programme}

A modern, illustrated regional Flora of Southern India was the first goal of the programme since all the three previous Floras (Hooker et al. 1872-1897, Gamble \& Fischer 1915-1936, Fyson 1932) were out-dated and inadequate. To improve the botanical knowledge of this region, field work was to be done in four zones (Fig. 1) of which the work in Zones 1 \& 2 has already been completed. Zone 1, covering the vegetation of the plains and low altitude hills $(<1400 \mathrm{~m})$ including eight out of the nine tribal belts of Tamil Nadu State, was the first zone (Matthew 1981, 1982, 1983 \& 1988). A similar illustrated Flora, covered the montane region of the Palni hills (Zone 2). The latter, part of the Western Ghats of India, one of the 25 biodiversity hotspots of the planet (Mittermeier et al. 1998), also suffered from massive introduction of alien species, cultivated or weedy, since the arrival of overseas personnel from the $1840 \mathrm{~s}$ (Matthew 1996, 1998a \& 1999a).

The technical programme for Zones 1 \& 2 was described (Matthew 1998c, 1997) under the following headings: 1 . The tract and field work; 2 . Documentation (Table 1); 3. Illustrations (Table 2); 4 . The Flora (Table 3) covering: analysis of materials; taxonomy; nomenclature and synonymy; keys; field notes; world distribution; and phytogeographical findings.

The volumes describing the flora of Zone 1 are now sold out, and instead of reprinting them, we are revising them with a considerable increase in field coverage and reassessment of the conservation status during the past quarter century. Zone 3, the Coromandel Coast, is being explored separately owing to historical antecedents (Roxburgh 1795-1820, Rottler 1803, Matthew 1993a), and the intense pressure from urbanisation in recent years. Zone 4 extends the area of Zone 1 northwards to the boundary of the State of Andhra Pradesh, and includes the Javadi hills, the only tribal 
belt of the State not included in Zone 1. From the field data from Zones 1 \& 2 a comprehensive conservation report on the extinct, endangered and rare species was published (Matthew 1999b) (Table 4).

Map of S. India : Exploration Zones (1-4)

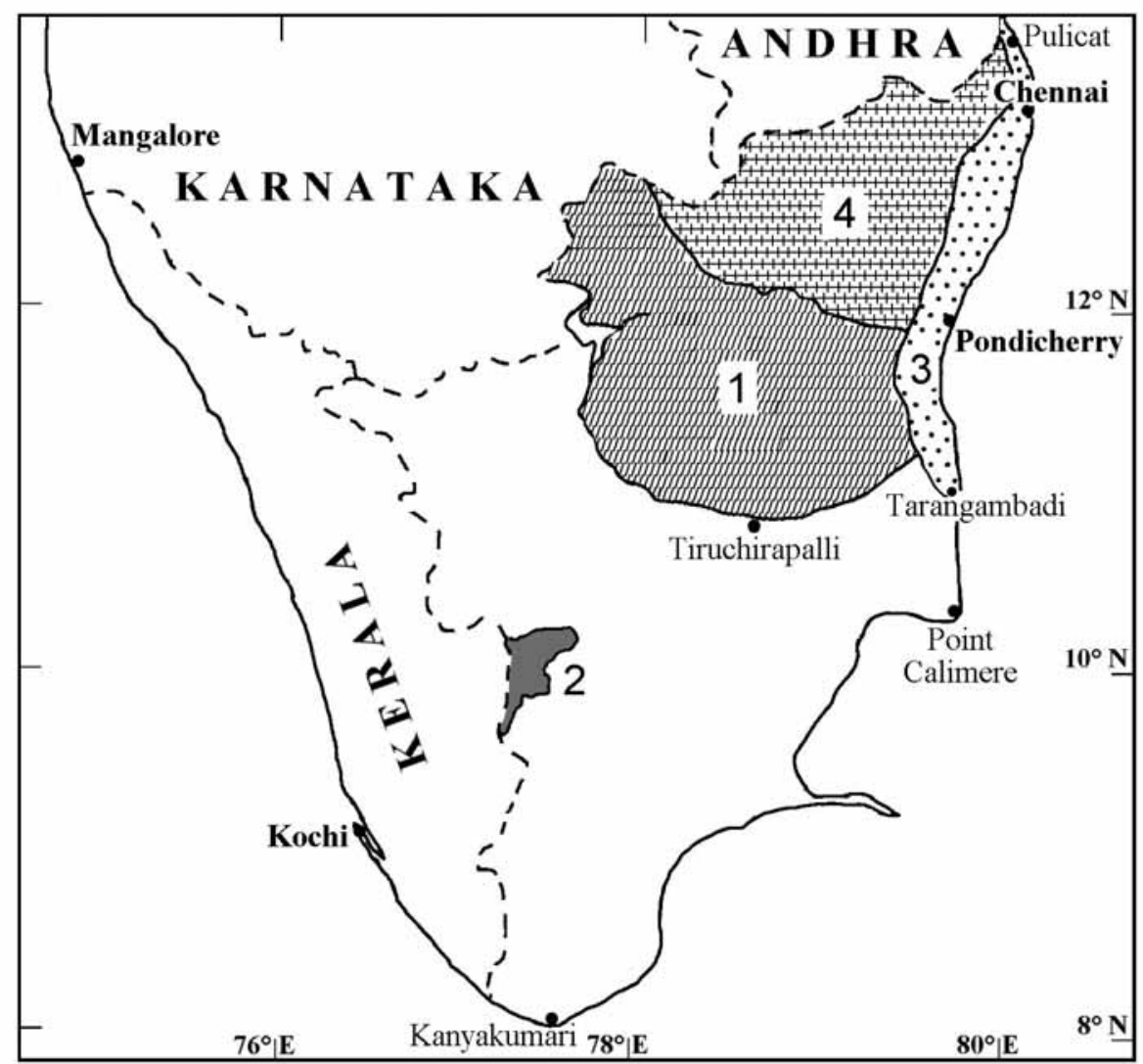

Fig. 1. Map of South India showing the four exploration zones. 
Table 1: Details of exploration work.

\begin{tabular}{|l|l|l|l|l|l|l|}
\hline Zone & Area & Duration & \multicolumn{3}{|c|}{ Number of } & Publications (Books only) \\
\hline & & & Field Days & Collections & Species & \\
\hline 1 & Plains: low altitute hills & $\begin{array}{l}1976- \\
1983\end{array}$ & 631 & 30722 & 2037 & $\begin{array}{l}\text { Matthew 1981, 1982, } \\
1983,1988,1991,1993 \mathrm{~b}, \\
1995,1998 \mathrm{~b}\end{array}$ \\
\hline 2 & Palni hills (to 2410 m) & $\begin{array}{l}1984- \\
1994\end{array}$ & 323 & 14987 & 2478 & $1996,1998 \mathrm{a}, 1999 \mathrm{a}$ \\
\hline 3 & Coromandel Coast & $2000-$ & 52 & 2177 & & \\
\hline 4 & North Tamil Nadu & $1999-$ & 82 & 3718 & & \\
\hline
\end{tabular}

Table 2: Details of plant illustrations.

\begin{tabular}{|l|l|l|}
\hline \multirow{2}{*}{ Publications } & \multicolumn{2}{|c|}{ Number of } \\
\cline { 2 - 3 } & Plates & Species \\
\hline Matthew 1982 & 960 & 882 \\
\hline 1983 & 111 & 14 \\
\hline 1988 & 834 & 820 \\
\hline 1996 & 950 & 903 \\
\hline $1998 a$ & 273 & 269 \\
\hline
\end{tabular}

Table 3: Classified conspectus of the included taxa.

\begin{tabular}{|c|c|c|c|c|c|c|c|}
\hline \multirow[t]{2}{*}{ Zone } & \multirow[t]{2}{*}{ Families } & \multirow{2}{*}{$\begin{array}{l}\text { Genera } \\
\text { (monotypic } \\
\text { in brackets) }\end{array}$} & \multicolumn{5}{|c|}{ Species } \\
\hline & & & Native & Naturalised & Cultivated & Garden & Total \\
\hline 1 & 180 & $990(486)$ & & & & 2037 & \\
\hline 2 & 202 & 1137 (377) & 1758 & 161 & 344 & 215 & 2478 \\
\hline 3 & & & \multirow{2}{*}{\multicolumn{3}{|c|}{ (Work in Progress) }} & & \\
\hline 4 & & & & & & & \\
\hline
\end{tabular}

Table 4: Conservation status of the endangered taxa (Matthew 1999b).

\begin{tabular}{|l|l|l|l|}
\hline \multirow{2}{*}{ Area Explored } & & Status of Species & \\
\cline { 2 - 4 } & Vulnerable & Presumed extinct & New Record (aliens excluded) \\
\hline Zone 1 & 25 & 3 & 6 \\
\hline Zone 2 & 65 & 13 & 56 \\
\hline Zone 3 & & (Work in Progress) & \\
\cline { 1 - 2 } Zone 4 & & & \\
\hline
\end{tabular}




\section{Community outreach}

\section{(i) Publications}

Involving the wider community has been integral to our 'lab to land' vision. Field Floras, first in English (Matthew 1991, 1995), later in the vernacular (Matthew 1993b, $1998 b)$, aimed at 'door delivery' of knowledge of local plants to the wider community. Pricing the publications within the purchasing power (at a quarter of the market rates) of any user, including students, was integral to this process. The issue of booksellers ignoring us because of our minimal pricing policy was initially considered a setback but eventually proved a boon: a direct producer-user link emerged, so that the users procured the publications directly from us, thereby eliminating the hefty profits to booksellers.

\section{(ii) The Herbarium, Library and Conservatory}

The long-term significance of the enrichment of the research herbarium (over 100000 collections added exclusively from the present work) as the indispensable starting point for all future plant-based research in the region, especially monography, cannot be over-emphasised. Furthermore, care has been taken to ensure that our collections are widely represented in overseas herbaria. The complete representation of all our species in the Royal Botanic Gardens Kew (K) will be a valuable extension to its holdings of historical collections from the region. Exchange with overseas centres has notably enriched our infrastructure, especially the library.

A Consultation Herbarium (each species of the region being represented by one or a very few sheets) maintained separately from the Research Herbarium is an easily accessible facility for those in search of names of local plants. This, incidentally, safeguards the latter from improper handling by amateurs.

The library, with a wide representation of periodicals and Floras, is widely used.

A Conservatory representing at least one species from all the local genera of plants, and adjacent to the Herbarium, is much appreciated by outside visitors. Live plants are a welcome change from the stuffy herbarium for ordinary people.

\section{Conservation research}

To have known at first hand the endangered plants in the field is the best stimulus to work for their conservation. This work, both in situ and ex situ, is organised at Kodaikanal, our environment centre. The availability of a high altitude base $(1800 \mathrm{~m})$ as a hill laboratory and field station is key to our conservation work, research and education. Such is The Anglade Institute of Natural History at Kodaikanal, $200 \mathrm{~km}$ away (from Tiruchirapalli), located inside the Nature Sanctuary of the Palni hills, and equipped with adequate natural history infrastructure.

Ex situ (off site) programmes: Crotalaria beddomeana Thoth. \& A.A. Ansari, originally described from the nearby Anaimalai hills, and reportedly doing well elsewhere, had nearly disappeared from the Palni hills. From a few seeds collected from a lone local plant, the species has been copiously regenerated and widely planted, so that it is now regarded as out of danger. The widespread planting of this robust shrub (over $3 \mathrm{~m}$ tall, with copious soil-enriching root nodules) by the local people, was an excellent example of community commitment to conservation.

Two other successful instances of ex situ conservation - Hoya wightii Hook.f. subsp. palniensis K.T. Mathew and Sonerila pulneyensis Gamble, are the work of VOYCE (Vattakkanal Organization for Youth, Community and Environment), a village-based 
Conservation Trust organized by R.W. Stewart and Tanya Balcar originally from the United Kingdom, now based near Pambar Shola.

In situ programmes: The in situ programmes are taken care of by the the Palni Hills Conservation Council (PHCC), a local conservation agency started in 1985, of which I was the Founder Vice-President. As a result of years of work, the Palni hills are to be declared a Nature Sanctuary contiguous with the Eravikulam National Park of the Anaimalais to the west. However, two constituent units have already been realized. Fencing of the Pambar Shola with the maximum concentration of endangered plants of the Palni hills, completed in 2000, has been decisively important. Replanting of its denuded slopes with local species by VOYCE is already in progress. Hedged in between the Pambar Shola and the 100-hectare campus of the Anglade Institute of Natural History is a notably intact slope with the maximum concentration of the folklore plant Strobilanthes kunthiana, probably the best known local plant on all the hills. This tract has been officially declared a "Kurinji (Strobilanthes) Reserve".

\section{Environmental education for the neighbourhood community}

The most innovative and successful part of our work has been the generation of mass environmental awareness for the neighbourhood community. The project has been an instant success since its inception in 1984, and has handled some 54000 trainees in the year-round, 3-day, live-in programmes. This is a free programme because the majority of the trainees cannot pay as they are in a permanent struggle for survival. Student intake figures for 1984-2001 are shown in Table 5.

(a) Insight: Starting from the grass-roots level and working upwards ensures lasting results through involvement of people. Particularly in today's environmental crisis, this insight is imperative. Our two main target trainees groups were: 1 . Students, the decisionmakers of tomorrow, and 2. Villagefolk, the custodians of the environment today.

A 3-step method was adopted: (i) supply of basic environmental information, largely from within the experience of the trainees, or closely related to it; (ii) motivating them to action; and (iii) equipping them with practical action programmes, thereby empowering them to be arbiters of their destiny.

(b) Objectives: Built on the 'watershed concept' and the role of primary vegetation in maintaining ecosystem balance, the entire programme was a series of demonstrations of natural processes. Lectures were conspicuous by their absence except for an occasional short keynote presentation, or a summing up of the main points illustrated by practical demonstrations. Eco-restoration is not only possible but imperative on everyone. Blaming someone else for the deteriorating environment is futile; it is time to take matters up oneself.

(c) Organisation: As trainees arrive for the 3-day programme (Monday-Wednesday, Thursday-Saturday), they are assured that no previous knowledge of biology is expected, nor even the ability to read or write. All that is expected is an interest in life. The resounding concurrence from the unlettered was a clear indication that we had breached the conventional barriers and reached the core of the trainees. They were engaged, and plunged themselves into the programme.

Day 1: Indoor exposure to the natural riches of the hills as conserved in the Institute: Museum, Gardens, Display Gallery, Reading Room. The intended result was a general appreciation of the riches of nature in the region. A wide selection of videos, also from other parts of the world, reinforced the experience.

Day 2: Outdoor exposure to nature: during half-a-day, visiting some pre-determined spots around Kodaikanal, like intact forests contrasted with others gradually being 
cleared, monocultures etc., evoking a comparison with the previous day's indoor exposure. The trainees appreciate the urgency of the need of eco-restoration as a personal obligation. This field trip has always remained the high point of the entire programme. The afternoon is given to the Display Gallery where environmental information (regional and global) is displayed through pictures and figures that even illiterate people can follow. A Reading Room with environmental newsletters and periodicals, and some key books, helps to integrate the information. The very successful cultural programme by the trainees on environmental themes is ample proof that the message was getting home.

Day 3: Evaluation and action programmes. That the tax-payer had met the expenses for their taking part in the programme (no charges are made) renders this programme a loan the students had been given, to be returned in the form of service, noblesse oblige. The trainees come up with practical steps they can implement back home: nature clubs, greening, dissemination of information in their institutions and neighbourhood, cultural programmes, adopting a neighbourhood village, etc.

Leadership programmes: The need for leadership programmes was discovered in course of time with a view to training of trainers (multiplier effect). Leaders need additional informational inputs and interaction with similar groups elsewhere. Besides one national programme in English, there are at least five zonal programmes in the vernacular (Fig. 3). These are organized by our zonal co-ordinators who are the backbone for quality performance. They carefully screen the applicants and approve only promising ones. Copies of our Handbook, in English and in the vernacular (Matthew 1987, 1992, 1994 \& 1997), also sold cheaply, are a handy souvenir for the trainees.

(d) Programme outreach (Figs 2 \& 3). The 415 centres from where the trainees have come are potential centres for environmental sensitivity to be set into action. This hope was confirmed during the Impact Assessment visits to the trainee centres by our staff. It is essential that this network of environmental initiatives and workers in the region be actively maintained. This is the purpose of Shola, our 6-monthly, bi-lingual environmental newsletter (28 issues published so far). Mailing of some 100 copies to overseas centres keeps us in touch with the global pulse.

Table 5: Participation figures 1984-2001

\begin{tabular}{|l|l|l|l|l|l|l|l|}
\hline Years & \multicolumn{5}{|c|}{ Number of } & Total \\
\hline & Courses & Students & Teachers & Leaders & Activists & Villagers & \\
\hline $1984-2001$ & 1170 & 36475 & 2356 & 1416 & 2951 & 10545 & 53743 \\
\hline
\end{tabular}

\section{Conclusion}

The significance of the work reported here is the stepwise integration of three programmes, and relating them to the wider community around who gradually should assume responsibility for their future. The relevance and urgency of this approach, especially in the tropics, the home of the bulk of the planet's green cover now under growing threat, is obvious. The scheme outlined here can easily be replicated anywhere, at least as to its major components. 


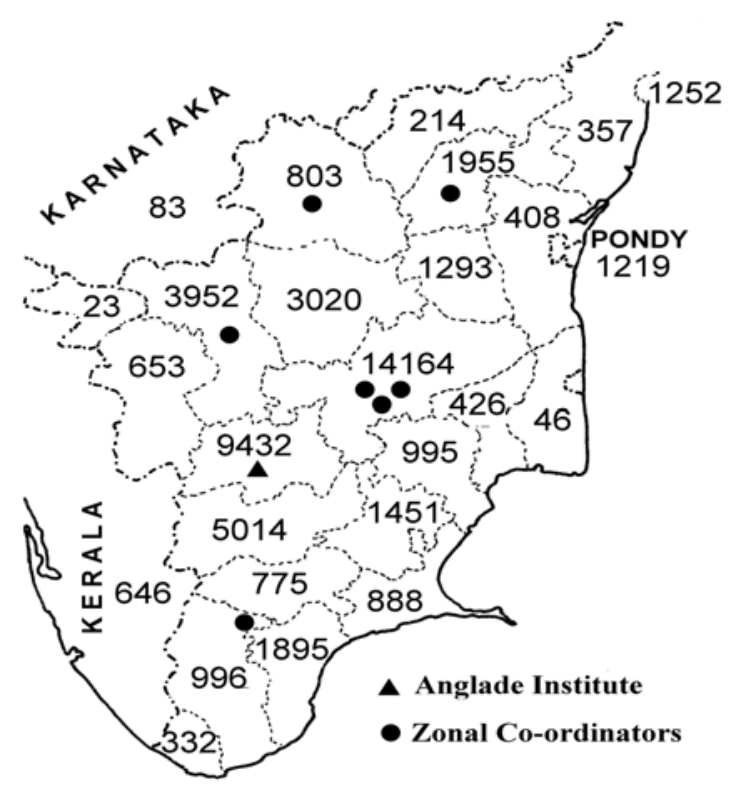

Fig. 2. Map of South India showing the geographical coverage under the Grass-roots Programme.

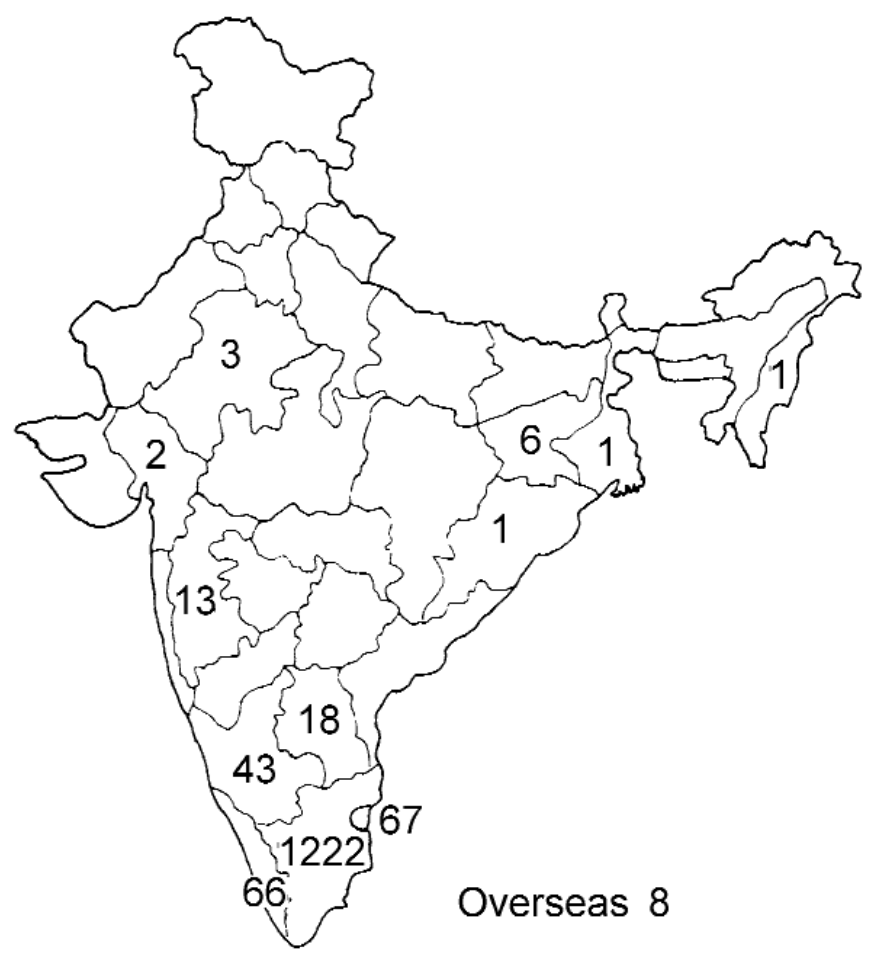

Fig. 3. Map of India showing the geographical coverage under the Leadership Programme. 


\section{References}

Fyson, P.F. (1932) The Flora of the South Indian Hill Stations. (Government Press: Madras).

Gamble, J.S. \& Fischer, C.E.C. (1915-1936) Flora of the Presidency of Madras. 3 vols (West Newman \& Co., Adlard \& Son: London).

Hooker, J.D. et al. (1872-1897) The Flora of British India. 7 vols. (L. Reeve \& Co.: London) .

Matthew, K.M. (1981) Materials for a Flora of the Tamilnadu Carnatic. (Rapinat Herbarium: Tiruchirapalli).

Matthew, K.M. (1982) Illustrations on the Flora of the Tamilnadu Carnatic. (Rapinat Herbarium: Tiruchirapalli).

Matthew, K.M. (1983) The Flora of the Tamilnadu Carnatic. (Rapinat Herbarium: Tiruchirapalli).

Matthew, K.M. $(1987,1994)$ A Handbook of the Anglade Institute of Natural History, Shembaganur. (Rapinat Herbarium: Tiruchirapalli).

Matthew, K.M. (1988) Further Illustrations on the Flora of the Tamilnadu Carnatic. (Rapinat Herbarium: Tiruchirapalli).

Matthew, K.M. (1991, 1995) An Excursion Flora of Central Tamilnadu, India. (Oxford \& IBH Publishing: New Delhi).

Matthew, K.M. $(1992,1997)$ Tamil translation of the Handbook by S. John Britto. (Rapinat Herbarium: Tiruchirapalli).

Matthew, K.M. (1993a) Notes on an important botanical trip (1799-1800) of J.P. Rottler on the Coromandel Coast (India) with a translation of his original text, explanatory notes and a map. Botanical Journal of the Linnean Society 113: 351-388.

Matthew, K.M. (1993b, 1998b) Tamil translation of the Excursion Flora by S. John Britto. (Rapinat Herbarium: Tiruchirapalli)

Matthew, K.M. (1996) Illustrations on the Flora of the Palni Hills, South India. (Rapinat Herbarium: Tiruchirapalli)

Matthew, K.M. (1998a) Supplement to Illustrations on the Flora of the Palni Hills, South India. (Rapinat Herbarium: Tiruchirapalli).

Matthew, K.M. (1998c [1997]) A Flora of Tamilnadu, South India. In Dransfield J., Coode MJE, Simpson DA, eds, Plant Diversity in Malesia III: Proceedings of the Third International Flora Malesiana symposium 1995. Kew. Royal Botanic Gardens, Kew (1998 [1997]), pp. 141-151.

Matthew, K.M. (1999a) The Flora of the Palni Hills, South India. (Rapinat Herbarium: Tiruchirapalli).

Matthew, K.M. (1999b) A report on the conservation status of South Indian plants. Biodiversity and Conservation 8: 779-796.

Mittermeier, R., Bowles, I. \& Konstant, W. (1998) Biodiversity hotspots revealed. People and the Planet 7(4): 10-15.

Rottler, J.P (1803) Botanische Bemerkungen auf der Hin- und Rückreise von Trankenbar nach Madras von Herrn Missionar Rottler zu Trankenbar mit Anmerkungen von Herrn Professor C.L. Willdenow. Neue Schriften der Naturforschender Freunde zur Berlin 4: 180-224.

Roxburgh, W. (1795-1820) Plants of the Coast of Coromandel, 3 vols. (W.Bulmer and Co.: London). 